\title{
THE IMPACT OF CONTEXTUAL FACTORS ON TOTAL QUALITY MANAGEMENT PRACTICES
}

\author{
Esin SADIKOĞLU \\ Cemal ZEHIR \\ Gebze Institute of Technology, Turkey
}

\begin{abstract}
There are mixed results about the effect of the contextual variables on the total quality management (TQM) practices. This study investigated contingency effects of firm size and firm type on quality management practices. For this purpose, we identified TQM variables as leadership, employee management, information and analysis, supplier management, process management, customer focus, and continuous improvement after reviewing the literature. The study used cross-sectional surveymethodology and sent 500 questionnaires to ISO-9001:2000 certified firms in different industries in the Marmara region in Turkey in the years of 2005 and 2006. The results show that firm size statistically significantly affects TQM practices. Large firms implemented employee management, information and analysis, supplier management, and continuous improvement practices more intensively than small firms. The results also show that firm type does not statistically significantly affect TQM practices. One exception was that manufacturing firms implemented information and analysis practices more heavily than service firms.
\end{abstract}

Key words: Total quality management, firm size, firm type

\section{INTRODUCTION}

Total quality management (TQM) is a holistic quality improvement approach to firms by means of continuously improving products, services, people, processes, and environment involving all employees to satisfy customers and maximize competitiveness of the firms. The benefits of TQM are improved customer satisfaction, quality of goods and services, productivity, delivery times, employee participation, and employee satisfaction as well as reduced waste, inventory, cost, product development time, and workin-process among others (Evans and William, 1993; Lowery et al., 2000; Besterfield et al., 2003; Goetsch and Davis, 2006).

While there are many success stories of TQM practices, some authors (e.g. Douglas and Judge, 2001) have claimed that TQM practices failed. Some reasons of TQM discontinuance were being context-dependent, lack of senior management commitment, lack of understanding of TQM, and lack of involvement of employees in TQM practices, lack of planning for quality, lack of resources of small firms for quality, and lack of customer focus (e.g. Sila, 2007, Bohan, 1998; Masters, 1996; Whalen and Rahim, 1994; McCabe et al., 1998; cf. Smith et al., 1993; Taylor and Wright, 2003; Sebastianelli and Tamimi, 2003). In conjunction with this, the knowledge of quality context is useful in predicting the level of TQM practices since the perceptions of ideal and actual quality management practices change with the business units' quality context (Benson et al., 1991) and inertial forces may prevent to implement TQM practices while TQM practices are imperative to become competitive 
(Shah and Ward, 2003). The intensity of TQM practices depends on the versions of industry sectors, market conditions, organization sizes, and the stages of quality development (Hills, 1995). Although TQM philosophy states TQM is universally applicable and homogenous, TQM practices are contingent with and tailored according to the context of the organization (cf. Prajogo and Sohal, 2001).

There are mixed results about the effect of the contextual variables on the TQM practices (e.g. Benson et al., 1991; Shah and Ward, 2003; Taylor, 1998; Shrivastava et al., 2006; Anderson et al., 1995). For example, Benson et al. (1991) found most of the contextual variables did not statistically affect TQM practices although TQM practices were not context free.

Some scholars (e.g. Sila, 2007, Shah and Ward, 2003; Prajogo and Sohal, 2001, 2004) suggest study the effect of the contextual factors such as firm size and firm type on the TQM practices in the future studies. The objective of this study was to investigate the contingency effects of firm size and firm type on the quality management practices.

\section{LITERATURE REVIEW AND STATEMENT OF THE HYPOTHESES}

We identified the TQM variables as leadership, employee management, information and analysis, supplier management, process management, customer focus, and continuous improvement after reviewing the literature. Specifically, we adopted the items for customer focus practices from the studies of Rahman and Bullock (2004), Chong and Rundus (2004), and Fuentes et al. (2004); the items for leadership practices from the studies of Cua et al. (2001); the items for employee management practices from the studies of Cua et al. (2001), Rahman and Bullock (2004), and Fuentes et al. (2004); the items for process management practices from the studies of Cua et al. (2001) and Saraph et al. (1989); the items for continuous improvement practices from the studies of Saraph et al. (1989), Rahman and Bullock (2004), and Fuentes et al. (2004); the items for information and analysis practices from the studies of Saraph et al. (1989), Cua et al. (2001), and Fuentes et al. (2004); the items for supplier management practices from the studies of Rahman and Bullock (2004) and Kannan and Tan (2005).

\section{Firm Size}

There are different views about the effect of firm size on the TQM practices. One viewpoint states that large firms implement TQM practices more heavily than small firms. Small firms are less knowledgeable about and aware of TQM practices such as customer focus than large firms. Also, small firms confuse TQM practices with quality assurance and ISO 9000 most often. They have less motivation to pursue TQM practices than large firms as well. Further, small firms do not measure customer satisfaction as frequently as large firms and they are less likely to measure the impact of TQM practices on performance (cf. Taylor, 1998). The study of Taylor et al. (2003) gives the majority of the firms who discontinued TQM were small firms. On the other hand, large organizations are more decentralized, specialized, and formalized than small firms. They have available abundance of capital resources to deploy TQM practices, more market influence, professional managerial expertise, and human resources that will facilitate TQM implementation and return to scale for investment of the TQM practices (cf. Sila, 2007, Cua et al., 2001; cf. Ahire and Dreyfus, 2000; Shah and Ward, 2003). The impact of TQM practices on the financial benefits in an organization has been observed after five to eight years of the TQM implementation (Dusseau, 1996; Goetsch and Davis, 2006). Since small firms expected the benefits from TQM sooner, they were generally disappointed (cf. Shrivastava et al., 2006).

The opposite viewpoint states small firms are more successful in implementing the TQM practices. The reasons are that small firms have flatter organization, higher flexibility, more customer orientation, less complexity, more informal communication, and more tendencies to implement innovative work practices than large firms. (cf. Ahire and Dreyfus, 2000; cf. Sila, 2007). On the other hand, large firms are more likely to have more layers of management, more functional lines (i.e. barriers between the departments), have bigger bureaucracy, and greater formalization than small firms (Daft, 1995). Also, administrative tasks may make the large firms so complicated that the employees may insist on the existent system to continue and resist change. Thus, large firms may face strong inertial forces that will put roadblocks to successful TQM efforts, thus, will cause waste of time and money to implement and maintain the TQM practices (cf. Shah and Ward, 2003; cf Hendricks and Singhal, 2001).

There are mixed results about the effect of firm size on the TQM implementation. Some authors (e.g. Sila, 2007; Ahire and Dreyfus, 2000; Taylor and Wright, 2003; Taylor, 1998; Benson et al., 1991; Taylor et al., 2003) found that firm size had no effect on the variation 
in the quality management practices (perceived TQM success), which improve organizational performance of the firms.

However, some authors (e.g. Ismail et al., 1998; Shah and Ward, 2003; Shrivastava et al., 2006; Yoo, 2003) found firm size had a positive effect on the quality management practices: large firms implemented TQM practices more than small firms. Shrivastava et al. (2006) found firm size statistically significantly affected TQM practices of proactive business orientation, internal support, and competitive assessment in favor of large firm although there was no effect on the participatory orientation practices. Yoo (2003) found large firms had more the TQM efficiency, which was defined as the ratio of quality improvement (output) to the TQM practices (input), than small firms.

There are also opposite results about the contingency effect of firm size on the TQM practices. Some authors (e.g. Powel, 1995; Hendricks and Singhal, 2001; Ahire and Golhar, 1996) found that firm size statistically significantly and negatively affected successful TQM efforts. Their result showed that small firms implemented TQM more effectively and they benefited more than large firms. Ahire and Golhar (1996) found that small firms implemented customer focus and SPC usage better than large firms while firm size did not significantly affect the other TQM practices. Based on the reviewed literature, the following hypothesis is suggested in the null form:

H1: Firm size does not affect the TQM practices.

\section{Firm Type}

Industry structural characteristics may affect successful TQM efforts. For example, when an industry's volatility and global competitiveness increases, its incentive to implement TQM practices also increases. Further, logistical complexity of a production system of an industry positively affects effectiveness of the TQM practices (cf. Ahire and Dreyfus, 2000).

Manufacturing firms implement TQM more highly and routinely than service firms since they define, operationalize, and control their processes more strictly than service firms. Also, manufacturing firms with their customers and suppliers are more aware of quality issues than service firms. Further, manufacturing firms are ahead of service firms in terms of struggling quality problems and opportunities (Benson et al., 1991). Moreover, supply chain management is rooted in the manufacturing industry and manufacturing firms are more proactive in supplier management practices (cf. Shrivastava et al., 2006).

There are mixed results on the effect of firm type on the TQM practices. Some authors (e.g. Ahire and Dreyfus, 2000; Shah and Ward, 2003) found that firm type did not statistically significantly affect the TQM practices. Shrivastava et al. (2006), however, found that service firms implemented proactive business orientation and participatory orientation practices more intensively than manufacturing firms although they implemented internal support practices less than manufacturing firms. Their study also showed firm type did not statistically affect competitive assessment practices. Rungtusanatham et al. (1998) found firm type affected visionary leadership and process management practices while it did not statistically significantly affect internal and external cooperation, learning, and continuous improvement practices. Based on the reviewed literature, the following hypothesis is offered in the null form:

H2. Firm type does not affect the TQM practices.

\section{RESEARCH METHODOLOGY}

We used cross-sectional survey methodology in this study. The sample was selected randomly among the firms who have ISO 9001: 2000 quality assurance system certificates in the different industries in the Marmara region in Turkey. Although being ISO-9000 certified does not assure achieving real improvements in quality of the processes, products or services and the intensity of the TQM implementation in the firm (Taylor and Wright, 2003), it is compatible and a subset of the TQM practices (Goetsch and Davis, 2006; Montgomery, 2005). Thus, it can be considered being a head start on the TQM journey and we used ISO-certified firms as respondents as Conca et al. (2004) did. We sent 500 questionnaires to the firms in the years of 2005 and 2006. We promised the respondents to keep the confidentiality of their responses and to send the general firm profile in response to participating in the survey in the cover letter to obtain a high response rate. The respondents completed the questionnaires mostly via face-to-face interview but they also participated in the survey by mail, e-mail, and fax. We obtained 373 usable questionnaires giving the respond rate as 74.6 percent.

We developed multiple TQM factors in the questionnaire namely leadership, employee management, information and analysis, supplier management, process management, customer focus, and continuous improvement. The questionnaire included a five-point Likert-type scale anchored at (1) strongly disagree and (5) strongly agree, indicating their disagreement or agreement with each item. Thus, 
we requested perceived (subjective) data from the respondents to measure the intensity of TQM practices of the firm. We also substituted the missing values in the questionnaires with the mean of the corresponding item before performing the analysis.

We conducted exploratory factor analysis using principle components extraction with varimax rotation to identify factors with eigenvalues of at least one to obtain more easily interpretable factor loadings. We also operationalized a single composite TQM, which equals the aggregate of the means of all TQM factors. TQM index can be formulated as follows:
TQMindex $=\sum_{i=1}^{7} \frac{\sum_{i=1}^{m_{i}} \text { item }_{i j}}{m_{i}}$

Where item $_{i j}$ is $j^{\text {th }}$ measurement item of the $i^{\text {th }}$ factor's measurement scale and $m_{i}$ is the number of the measurement items in the $i^{\text {th }}$ factor's measurement scale. After confirming validity and reliability of the observed variables, we performed t-test statistical analysis to test the hypotheses.

EXIHIBIT 1 Results of factor analysis and reliabilities of the TQM practices

\begin{tabular}{|c|c|c|c|}
\hline & Scale item & Factor loading & Eigenvalues \\
\hline \multirow[t]{6}{*}{ Leadership } & $\mathrm{L} 1$ & 0.675 & $9.25 \%$ \\
\hline & L2 & 0.659 & \\
\hline & L3 & 0.643 & \\
\hline & L4 & 0.642 & \\
\hline & L5 & 0.636 & \\
\hline & L6 & 0.570 & \\
\hline \multirow[t]{6}{*}{ Employee management } & EM1 & 0.801 & $10.53 \%$ \\
\hline & EM2 & 0.770 & \\
\hline & EM3 & 0.745 & \\
\hline & EM4 & 0.653 & \\
\hline & EM5 & 0.637 & \\
\hline & EM6 & 0.633 & \\
\hline \multirow[t]{5}{*}{ Information and analysis } & IA1 & 0.669 & $6.91 \%$ \\
\hline & IA2 & 0.624 & \\
\hline & IA3 & 0.602 & \\
\hline & IA4 & 0.573 & \\
\hline & IA5 & 0.550 & \\
\hline \multirow[t]{5}{*}{ Supplier management } & SM1 & 0.815 & $8.94 \%$ \\
\hline & SM2 & 0.779 & \\
\hline & SM3 & 0.726 & \\
\hline & SM4 & 0.677 & \\
\hline & SM5 & 0.567 & \\
\hline \multirow[t]{5}{*}{ Process management } & PM1 & 0.790 & $9.21 \%$ \\
\hline & PM2 & 0.770 & \\
\hline & PM3 & 0.727 & \\
\hline & PM4 & 0.722 & \\
\hline & PM5 & 0.573 & \\
\hline \multirow[t]{7}{*}{ Customer focus } & CF1 & 0.745 & $10.96 \%$ \\
\hline & CF2 & 0.697 & \\
\hline & CF3 & 0.693 & \\
\hline & CF4 & 0.669 & \\
\hline & CF5 & 0.647 & \\
\hline & CF6 & 0.627 & \\
\hline & CF7 & 0.627 & \\
\hline \multirow[t]{4}{*}{ Continuous improvement } & CI1 & 0.808 & $8.36 \%$ \\
\hline & CI2 & 0.762 & \\
\hline & CI3 & 0.738 & \\
\hline & CI4 & 0.738 & \\
\hline
\end{tabular}


EXHIBIT 2 Descriptive statistics and Cronbach's alpha values of the TQM practices

\begin{tabular}{|l|r|r|r|}
\hline & Mean & Standard deviation & Alpha value \\
\hline Leadership & 3.99 & 0.64 & 0.83 \\
\hline Employee management & 3.63 & 0.76 & 0.88 \\
\hline Information and analysis & 3.98 & 0.64 & 0.80 \\
\hline Supplier management & 3.69 & 0.78 & 0.87 \\
\hline Process management & 3.70 & 0.81 & 0.88 \\
\hline Customer focus & 4.14 & 0.65 & 0.87 \\
\hline Continuous improvement & 3.82 & 0.85 & 0.89 \\
\hline TQM index & 26.95 & 3.98 & 0.97 \\
\hline
\end{tabular}

\section{RESULTS OF THE ANALYSIS}

\section{Sample Demographics}

Approximately 57 percent of the respondents (205) were managers, which included senior managers (top manager, vice manager, human resource manager, and total quality manager), middle managers (department manager and chief), and low-level managers (foremen). About 43 percent of the respondents (155) were employees, which included engineers and technicians. About 54.4 percent of the firms (203) were service firms, which included transportation, information technology, finance, healthcare, and other service firms. About 45.6 percent of the firms (170) were manufacturing firms, which included textile, metallurgy / chemistry, food, furniture, and other manufacturing firms. Approximately 52.3 percent of the firms (195) were small and medium sized firms having number of employees less than or equal to 250 and 46.1 percent of the firms (172) were large firms having number of employees more than 250 . About 79 percent of the firms (260) operated nationally and 30 percent of the firms operated internationally. Approximately, 98 percent of the firms (366) were private firms and 2 percent of the firms (7) were public firms.

\section{Results of the Factor Analysis}

Before performing principal component analysis, we measured the homogeneity of the data for sampling adequacy. The result of Kaiser-Meyer-Olkin (KMO) measure is 0.937 , which is greater than the "middling" value of 0.7 (cf. Black and Porter, 1995), and the result of Bartlett's Test (BT) is 0.000 , which is less than 0.05 . Thus, the results show that data have homogeneity and adequacy for principal component analysis.

We discarded the items that did not fit the observed variables adequately and had factor loadings of less than 0.50 in the exploratory factor analysis. Exhibit
1 gives the results of factor analysis and reliabilities of the TQM practices. As clearly noticed from the exhibit, the final measurement instrument included seven TQM factors with 38 items and the factors explained 64.16 percent of the total variance.

\section{Tests for Reliability and Validity of the Constructs}

Exhibit 2 exhibits descriptive statistics and Cronbach's alpha values of the variables in the research model. Internal consistency reliability of the multiple item measurement scale is measured by Cronbach's alpha. We made reliability analysis to ensure that the scale items measured the corresponding TQM observed variables consistently and were free of measurement error by using Cronbach's alpha (cf. Kannan and Tan, 2005). Since the TQM index variable is operationalized as an aggregate of mean scores of the seven TQM factor measurement scales, we calculated its reliability from the formula given in the study of Rungtusanatham (2001, pp. 666). We found the reliability of the TQM index was 0.97 . It is easily noticed from Exhibit 2 that alpha values of the TQM practices and TQM index measures ranged from 0.80 to 0.97 , and surpassed 0.70 threshold. Thus, the alpha values provide satisfactory reliabilities of the constructs.

Content validity is the extent of coverage of the items in the issues measured and is subjectively evaluated by the researchers. We consider the instrument has content validity since the scale items of TQM factors were adapted from literature. Construct validity assesses how well the individual item measured the scale. For this purpose, we retained items that had a factor loading of at least 0.50 (cf. Kaynak, 2003). As clearly seen from Exhibit 1, all factor loadings of the TQM scales exceed 0.50 threshold. Thus, the instrument satisfies construct validity. 


\section{Results of $t$ Test Analysis}

As clearly seen from Exhibit 2, firms, in general, had positive levels of TQM implementation (mean > 3) according to the definition given by Lai et al. (2002). The firms also, on average, implemented customer focus, leadership, and information and analysis practices more intensively than the other TQM practices.

Exhibits 3 and 4 give $t$ test results for equality of means of the TQM practices according to firm size and firm type, respectively. As clearly noticed from
Exhibit 3, firm size, in general, statistically significantly affects the TQM practices and TQM index. Firm size statistically significantly affects employee management, information and analysis, supplier management, and continuous improvement practices. However, firm size does not statistically significantly affect leadership, process management, and customer focus practices.

On the other hand, as clearly seen from Exhibit 4, firm type, in general, does not statistically significantly affect the TQM practices and TQM index. Firm type does only statistically significantly affect information and analysis practices.

EXHIBIT 3. T test for equality of means of the TQM practices with respect to firm size

\begin{tabular}{|l|r|r|r|r|}
\hline & t value & df & Sig. (2-tailed) & Results \\
\hline Leadership & -0.246 & 365 & 0.806 & Insignificant \\
\hline Employee management & -2.841 & 330 & $\mathbf{0 . 0 0 5 * * *}$ & Significant \\
\hline Information and analysis & -3.008 & 336 & $\mathbf{0 . 0 0 3 * * *}$ & Significant \\
\hline Supplier management & -2.375 & 365 & $\mathbf{0 . 0 1 8}^{* *}$ & Significant \\
\hline Process management & -1.613 & 365 & 0.108 & Insignificant \\
\hline Customer focus & 0.275 & 365 & 0.784 & Insignificant \\
\hline Continuous improvement & -4.012 & 365 & $\mathbf{0 . 0 0 0 * * *}$ & Significant \\
\hline TQM index & -2.624 & 317 & $\mathbf{0 . 0 0 9 * * *}$ & Significant \\
\hline
\end{tabular}

* Significant at the 0.10 level.

** Significant at the 0.05 level.

*** Significant at the 0.01 level.

EXHIBIT 4. T test for equality of means of the TQM practices with respect to firm type

\begin{tabular}{|l|r|r|r|r|}
\hline & t value & df & Sig. (2-tailed) & Results \\
\hline Leadership & 1.643 & 371 & 0.101 & Insignificant \\
\hline Employee management & 0.634 & 371 & 0.527 & Insignificant \\
\hline Information and analysis & 2.392 & 371 & $\mathbf{0 . 0 1 7 ^ { * * }}$ & Significant \\
\hline Supplier management & 1.027 & 371 & 0.305 & Insignificant \\
\hline Process management & 0.430 & 371 & 0.667 & Insignificant \\
\hline Customer focus & 0.937 & 371 & 0.332 & Insignificant \\
\hline Continuous improvement & -0.992 & 304 & 0.322 & Insignificant \\
\hline TQM index & 0.997 & 371 & 0.319 & Insignificant \\
\hline
\end{tabular}

* Significant at the 0.10 level.

** Significant at the 0.05 level.

*** Significant at the 0.01 level 


\section{DISCUSSION AND CONCLUSION}

The results show that firm size statistically significantly affects the TQM efforts. Large firms, on average, implemented the TQM practices more heavily than small firms. Specifically, large firms implemented employee management, information and analysis, supplier management, and continuous improvement practices more intensively than small firms. The reason may be that employees in the small firms do not have awareness, knowledge about and skills of the TQM practices and quality improvement techniques due to lack of training. This will result in lack of employee motivation to participate in teamwork and empowerment practices in the workplace. Thus, continuous improvement of the process, product or service will be lower than large firms. Small firms also do not have huge capital resources to train employees, to hire consultants and professional employees to deploy employee involvement and continuous improvement practices. In the same way, small firms do not have abundant resources to purchase an enterprise resource planning software or a supplier performance measurement database, which are crucial for obtaining and sharing consistent, current, reliable, and accurate information within the firm and between the supplier and the manufacturer to improve efficiency and effectiveness of the information and analysis practices and supply chain management efforts of the firm, respectively.

However, the results show that firm size does not statistically significantly affect leadership, process management, and customer focus practices. The reason for this result may be that while lacking capital resources as a disadvantage, small firms have employees who have leadership skills to motivate the other employees to see the big picture of the organization, to focus on the customer, to better manage process by making employees working both smart and hard to satisfy customers as large firms have. Software vendors recently have focused on and offered products, which are less costly and tailored to the needs of the SME firms. Small firms can successfully implement information and analysis and supplier management practices if they perform these softwares.

Although the results show that the TQM practices are not context free, firm type does not statistically significantly affect the TQM practices. One exception is that the manufacturing firms implemented information and analysis practices more heavily than service firms. The reason for this result may come from the fact that TQM and database management systems like enterprise resource planning software have rooted from the manufacturing industry. This may cause manufacturing firms being more aware and effective use of information and analysis practices. However, there are no statistical significant differences among the other TQM practices between manufacturing and service firms. The implication of these results for the managers are that service firms should commit more resources to implement information and analysis to obtain timely, reliable, accurate, and updated data and information to improve effectiveness, efficiency, and thus, competitiveness of the firm. The managers should motivate, train the employees and concern about the culture change needed to facilitate information management system.

This study has found that "one-size fits all" assumption is not satisfied. While TQM is universally applicable to any size and type of the firm, its degree of implementation is context dependent. Large firms, on average, implemented most of the TQM practices more intensively than small firms. Small firms should focus and commit more resources to improve effectiveness of employee management, information and analysis, supplier management, and continuous improvement efforts. However, there are no statistical significant differences among most of the TQM practices with respect to firm type. One exception is that manufacturing firms implemented information and analysis more intensively than service firms. Service firms should commit more resources to improve information and analysis efforts to be successful in the TQM journey.

\section{LIMITATIONS OF THE STUDY}

Self-report or common method variance might occur since all questionnaire items were completed by the same respondent in the firm. We performed Harman's one-factor test to isolate artifactual covariance due to common method variance as a post-hoc remedy (Podsakoff and Organ, 1986). The result of Harman's single-factor analysis shows that there is more than one factor in the unrotated principal components factor analysis solution of all variables. Also, the first factor explains 36.59 percent of variance out of total 64.16 percent variance. Thus, there is no substantial amount of common method variance in the study. 
APPENDIX A. Measurement scales, survey items, and their sources

\section{A. Total quality management}

Only the items remained after factor analysis and reliability analysis were given the Appendix.

\section{A.1. Leadership}

All items in this scale were adapted from Cua's et al. (2001) study.

L1. All major department heads within our plant accept their responsibility for quality.

L2. Plant management provides personal leadership for quality products and quality improvement.

L3. All major department heads within our plant work towards encouraging JIT production.

L4. Our top management strongly encourages employee involvement in the production process.

L5. Plant management creates and communicates a vision focused on quality improvements.

L6. Plant management is personally involved in quality improvement projects.

\section{A.2. Employee management}

Items 1-5 and 6 in this scale were adapted from Cua's et al. (2001) and Rahman and Bullock's (2004) studies, respectively.

EM1. During problem solving sessions, we make an effort to get all team members' opinions and ideas before making a decision.

EM2. Our plant forms teams to solve problems.

EM3. In the past 3 years, many problems have been solved through small group sessions.

EM4. Problem solving teams have helped improve manufacturing processes at this plant.

EM5. Employee teams are encouraged to try to solve their problems as much as possible.

EM6. Ideas from production operators are actively used.

\section{A.3. Information and analysis}

All items in this scale were adapted from Saraph's et al. (1989) study.

IA1. Extent to which quality data (cost of quality, defects, errors, scrap, etc.) are used as tools to manage quality.

IA2. Extent to which quality data are used to evaluate supervisor and managerial performance.
IA3. Thoroughness of new product/service design reviews before the product/service is produced and marketed.

IA4. Clarity of product/service specifications and procedures.

IA5. Extent to which implementation / producibility is considered in the product/service design process.

\section{A.4. Supplier management}

All items in this scale were adapted from Kannan and Tan's (2004) study.

SM1.Considering manufacturability and assembly in product design.

SM2.Emphasizing quality instead of price in supplier selection.

SM3.Considering commitment to quality in supplier selection.

SM4.Considering process capability in supplier selection.

SM5.Considering commitment to continuous improvement in supplier selection.

\section{A.5. Process management}

Items 1-4 and 5 in this scale were adapted from Cua's et al. (2001) and Saraph's et al. (1989) studies, respectively.

PM1. A large percent of the equipment or processes on the shop floor are currently under statistical quality control.

PM2. We make extensive use of statistical techniques to reduce variance in processes.

PM3. We use charts to determine whether our manufacturing processes are in control.

PM4. We monitor our processes using statistical process control.

PM5. Amount of final inspection, review, or checking.

\section{A.6. Customer focus}

Items 1-2, 3-4, and 5-7 in this scale were adapted from Rahman and Bullock's (2004), Chong and Rundus's (2004), and Fuentes's et al. (2004) studies, respectively.

CF1. Customer requirements are disseminated and understood.

CF2. Know our customers' current and future needs.

CF3. We frequently are in close contact with our customers. 
CF4. Our customers frequently visit our plant.

CF5. Managers and supervisors encourage activities that improve customer satisfaction.

CF6. Satisfying our customers, and meeting their expectations, is the most important thing we do.

CF7. Senior executives behave in ways that increases the importance of customers.

\section{A.7. Continuous improvement}

All items in this scale were adapted from Saraph's et al. (1989) study.

CI1. Specific work-skills training (technical and vocational) given to hourly employees throughout the organization

CI2. Quality-related training given to hourly employees throughout the organization

CI3. Quality-related training given to managers and supervisors throughout the organization.

CI4. Training in the "total quality concept" (i.e. philosophy of company-wide responsibility for quality) throughout the organization.

\section{REFERENCES}

Ahire, S.L. and Dreyfus, P., (2000), The impact of design management and process management on quality: an empirical examination, Journal of Operations Management, 18, pp. 549-575.

Ahire, S.L. and Golhar, D.Y., (1996), Quality management in large vs. small firms, Journal of Small Business Management, 34(2), pp. 1-13.

Anderson, J.C., Rungtusanatham, M., Schroeder, R.G. and Devaraj, S., (1995), A path analytic model of a theory of quality management underlying the Deming management method: preliminary empirical findings. Decision Sciences 26(5), 637-658.

Benson, P.G., Saraph, J.V., Schroeder, R.G., (1991). The effects of organizational context on quality management: an empirical investigation, Management Science, 37(9), pp. 1107-1124.

Besterfield, D.H., Besterfield-Michna, C., Besterfield, G.H, and Besterfield-Sacre, M., (2003). Total quality management. Third Edition. Prentice Hall, New Jersey.

Black, S. and Porter, L.J., (1995), An empirical model for total quality management, Total Quality Management, 6(2), pp. 149-164.

Bohan, G., (1998), Whatever happened to TQM? or how a good strategy got a bad reputation, National Productivity Review, 17(4), pp. 3-16.

Chong, V.K. and Rundus, M.J.,(2004), Total quality management, market competition and organizational performance, The British Accounting Review, 36, pp. $155-172$.

Conca, J.F., Llopis, J., and Tari, J.J., (2004), Development of a measure to assess quality management in certified firms, European Journal of Operational Research, 156(3), pp. 683-697.

Cua, K.O., McKone, K.E. and Schoreder, R.G., (2001), Relationships between implementation of TQM, JIT and TPM and manufacturing performance, Journal of Operations Management, 19, pp. 675-694.

Daft, R.L., (1995), Organization Theory and Design, Fifth Edition, West Publishing Company, Mineapolis, St. Paul, MN.

Douglas, T.J. and Judge Jr., W.Q., (2001), Total quality management implementation and competitive advantage: the role of structural control and exploration, Academy of Management Journal, 44, pp. 158-169.

Dusseau, S.P., (1996). An analysis of the relationship between financial performance and total quality management implementation, Unpublished doctoral dissertation, University of Missouri-Rolla.

Evans, J.R. and Lindsay, W.M., (1993), The management and control of quality, West Publishing Company, Minneapolis/St. Paul. 
Fuentes-Fuentes, M.M., Albacete-Saez, C.A. and Llorens-Montes, F.J., (2004), The impact of environmental characteristics on TQM principles and organizational performance, Omega, 32(6), pp. 425442.

Goetsch, D.L. and Davis, S.B., (2006), Quality management: introduction to total quality management for production, processing, and services, fifth ed. Prentice Hall, New Jersey, USA.

Hendricks, K.B. and Singhal, V.R., (2001), Firm characteristics, total quality management, and financial performance, Journal of Operations Management, 19, pp. 269-285.

Ismail, M.Y., Baradie, M. and Hashmi, M.S.J., (1998), Quality management in the manufacturing industry: practice vs. performance, Computers and Industrial Engineering, 35(3-4), pp. 519-522.

Kannan, V.R. and Tan, K.C., (2005), Just in time, total quality management, and supply chain management: understanding their linkages and impact on business performance, Omega, 33(2), pp. 153-162.

Kaynak, H., (2003), The relationship between total quality management practices and their effects on firm performance, Journal of Operational Management, 21, pp. 405-435.

Lai, K.-H., Weerakoon, T.S. and Cheng, T.C.E., (2002), The state of quality management implementation: a cross-sectional study of quality-oriented companies in Hong Kong, Total Quality Management, 13(1), pp. 29-38.

Masters, R.J., (1996), Overcoming the barriers to TQM's success, Quality Progress, 29(5), pp. 53-55.

McCabe, D. and Wilkinson, A., (1998), The rise and fall of TQM: the vision, meaning and operation of change, Industrial Relations Journal, 29(1), pp. 1829.

Montgomery, D.C., (2005), Introduction to statistical quality control, fifth ed. John Wiley \& Sons, New Jersey, USA.

Podsakoff, P.M. and Organ, D.W., (1986), Self-reports in organizational research: problems and prospects, Journal of Management, 12(4), pp. 531-544.

Powell, T.C., (1995), Total quality management as competitive advantage: a review and empirical study, Strategic Management Journal, 16, pp. 15-37.

Prajogo, D.I. and Sohal, A.S., (2001), TQM and innovation: a literature review and research framework, Technovation, 21, pp. 539-558.

Prajogo, D.I. and Sohal. A.S., (2004), The multidimensionality of TQM practices in determining quality and innovation performance-an empirical examination, Technovation, 24, pp. 443-453.

Prajogo, D.I. and Sohal. A.S., (2006), The relationship between organization strategy, total quality management (TQM), and organization performance - the mediating role of TQM, European Journal of Operational Research, 168(1), pp. 35-50.

Rahman, S. and Bullock, P., (2005), Soft TQM, hard $\mathrm{TQM}$, and organizational performance relationships: an empirical investigation, Omega, 33, pp. 73-83.

Rungtusanatham, M., (2001), Beyond improved quality: the motivational effects of statistical process control, Journal of Operations Management, 19, pp. 653-673.

Rungtusanatham, M., Forza, C., Filippini, R. and Anderson, J.C., (1998), A replication study of a theory of quality management underlying the Deming method: insights from an Italian context, Journal of Operations Management, 7, pp. 77-95.

Saraph, J.V., Benson, P.G. and Schroeder, R.G., (1989), An instrument for measuring the critical factors of quality management, Decision Sciences, 20, pp. 810829.

Sebastianelli, R. and Tamimi, N., (2003),

Understanding the obstacles to TQM success, Quality Management Journal, 10(3), pp. 45-55.

Shah, R. and Ward, P.T., 2003. Lean manufacturing: context, practice bundles, and performance. Journal of Operations Management 21,129-149.

Shrivastava, R.L., Mohanty, R.P. and Lakhe, R.R., (2006), Linkages between total quality management and organizational performance: an empirical study for Indian industry, Production Planning \& Control, 17(1), pp. 13-30.

Sila, I., (2007), Examining the effects of contextual factors on TQM and performance through the lens of organizational theories: An empirical study, Journal of Operations Management, 25, pp. 83-109.

Taylor, W.A., (1998), TQM implementation: organization practices and information infrastructures, Omega, International Journal of Management Science, 26(6), pp. 715-727.

Taylor, W.A. and Wright, G.H., (2003), A longitudinal study of TMQ implementation: factors influencing success and failure, Omega, 31(2), pp. 97-111.

Whalen, M.J. and Rahim, M.A., (1994), Common barriers to implementation and development of a TQM program, Industrial Management, 36(2), pp. 19-21.

Yoo, H., (2003), A study on the efficiency evaluation of total quality management activities in Korean companies, Total Quality Management, 14(1), pp. 119-128. 